\title{
lese faul?
}

\section{Bruno Kissling}

Dr. med., Co-Chefredaktor PrimaryCare von der Gründung 2000 bis 2014, Hausarzt in Bern

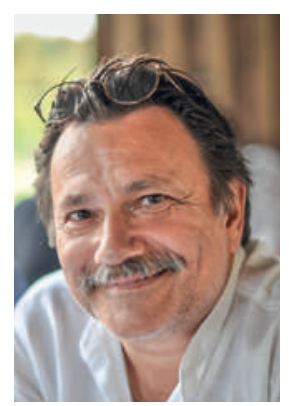

«Zu guter Letzt». Nein, es soll kein Nachruf auf meine langjährige Tätigkeit als Co-Chefredaktor von PrimaryCare sein. Lieber möchte ich über das Lesen und Schreiben sinnieren.

Ich war schon immer ein «fauler» Leser. Bücher der Schulbibliothek mussten sehr interessant sein, damit sie mich in Konkurrenz zu anderen Freizeitmöglichkeiten anlocken konnten. Gelandet bin ich paradoxerweise immer wieder bei den zeitintensiven, sprachgewaltigen alten Russen. Anhand meiner durchschnittlichen Lesewut und bescheidenen Schreibkunst hätten mich meine Deutschlehrer im Gymnasium kaum je als Chefredaktor einer Zeitschrift gesehen. Nun, wer kennt den Wert von Prognosen besser als wir Ärzte?

Kennen Sie die Spezies der "chaotischen" Leser? Auch dazu gehöre ich. Nicht, dass die Buchstaben nach meiner Lektüre wild durcheinandergeraten wären. Ich meine, einen Artikel in einer Zeitung oder Zeitschrift lese ich kaum je schön brav der Reihe nach

vom Anfang bis zum Schluss. Titel, Lead, Untertitel und Quotes springen mir attraktiv ins Auge. Sie verführen mich zum Lesen, vermitteln mir die wichtigsten Botschaften und geleiten mich orientierend durch den Artikel. Im Idealfall können sie mein Interesse wachhalten, bis ich keine neuen Abschnitte mehr entdecke und den ganzen Artikel gelesen habe. Ein guter Artikel geht respektvoll mit meiner limitierten Lesezeit um. So gewinnt er die Konkurrenz gegen zahllose Artikel in Unmengen von meistens nicht bestellten Zeitschriften, mit denen wir Ärzte tagtäglich überflutet werden.

«Less is more» war mein Credo als Chefredaktor und bleibt mein Motto als lesefauler und chaotischer Leser.

Wie liest Du, liebe Kollegin, lieber Kollege? Über diese Frage nachzudenken, überlasse ich Dir den restlichen Raum dieser renommierten Seite für Dein persönliches «Zu guter Letzt». 